\title{
Content Analysis of Teaching Competency in CBSE Textbooks in Mathematics of VI Standard
}

Manuscript ID:

EDU-2021-09044121

Volume: 9

Issue: 4

Month: September

Year: 2021

P-ISSN: 2320-2653

E-ISSN: 2582-1334

Received: 18.06.2021

Accepted: 26.08.2021

Published: 01.09.2021

Citation:

Manimozhi, G., and P. Srinivasan. "Content Analysis of Teaching Competency in CBSE Textbooks in Mathematics of VI Standard." Shanlax International Journal of Education, vol. 9, no. 4, 2021, pp. 169-77.

DOI:

https://doi.org/10.34293/ education.v9i4.4121

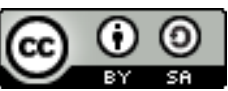

This work is licensed under a Creative Commons Attribution-ShareAlike 4.0 International License

\author{
G. Manimozhi \\ Department of Education, Research Scholar \\ Central University of Tamil Nadu, Thiruvarur, India \\ P. Srinivasan \\ Departments of Education, Associate Professor \\ Central University of Tamil Nadu, Thiruvarur, India
}

\begin{abstract}
Educational institutions are more concentrated on preferable measured outcomes rather than theoretical ones. Measuring subject knowledge obtains through written examination is easy, even as skills such as critical and logical thinking, decision making, problem-solving ability, creative thinking are difficult to measure. The education field is mostly based on students and teachers; teachers want to one kind of knowledge is competency, it is important for making the teachers professionally content and teaching competency is the ability to teach efficiently in clearing up the activities, manifesting activities, enjoin maintaining activities, documentation and record-keeping activities, task making activities, curriculum development activities and many kinds of activities. This study is analyzing the teaching competency in school textbooks. The main aim of the study is based on to compare the teaching competency dimensions to 6th standard CBSE mathematics textbook content.
\end{abstract}

Keywords: Teaching competency, CBSE Textbook and Content analysis.

\section{Introduction}

The teacher Profession is a necessity for students and our nation. The teacher is the key to acquaintance, knowledge and good judgment, understanding the critical problem and solution of problems in and out of the classroom for the child and essential knowledge about the rights, duties and the responsibilities of the Government through the teaching.

A large chasm exists among the usual and actual competencies of faculty members; in motivate the students to handle the challenges in the industry and society. Equipping students with 21st-century skills entails an additional set of competencies in faculty members. The faculty stay in an active environment that demands that they constantly obtain new skills, knowledge and attitude.

According to Kalaiselvi (2017), to develop the 21st-century skills in students, the faculty members are expected to possess the competencies such as Personal efficiency, Communication, Fostering a conducive environment for learning, Organising the curriculum, Continuous learning and Effective learning experience.

\section{Purpose of the Study}

Content analysis is an investigative tool used to determine the existence of assured words or concepts within texts or groups of texts. Researchers measure and analyze the occurrence, meanings and associations of such words and concepts, then obtain inferences about the information within the texts. 
Texts can be defined as books, chapters, books, essays, interviews, discussions, newspaper headlines, or any occurrence of a communication language. This study used content analysis to analyze the assured teaching competency dimensions assured and compared the 6 th maths school textbooks.

\section{Objectives of the Study}

- To find out teaching competency relationship in
CBSE Maths textbook of 6th standard.

- To find out the Planning, Presentation, closing, Evaluation and management of teaching competency in CBSE textbooks.

\section{Review of Related Literature}

The below table shows the review of literature based on the teaching competency studies.

Table 1: Teaching Competency Studies

\begin{tabular}{|c|c|c|c|c|}
\hline S.No & Authors Name & Title of the Study & Sample of the study & Findings of the Study \\
\hline 1 & $\begin{array}{l}\text { Ahmad \& Khan } \\
(2016)\end{array}$ & $\begin{array}{l}\text { A study of teaching } \\
\text { competency of secondary } \\
\text { school teachers in relation } \\
\text { to their educational } \\
\text { qualification, stream and } \\
\text { type of school }\end{array}$ & $\begin{array}{l}447 \text { secondary school } \\
\text { teachers }\end{array}$ & $\begin{array}{l}\text { The study revealed that govt. } \\
\text { teachers are dominating } \\
\text { private teachers at secondary } \\
\text { level on the basis of their } \\
\text { teaching competency; UG } \\
\text { \& PG qualification does } \\
\text { not affect the teaching } \\
\text { competency and science } \\
\text { teacher is better than the arts } \\
\text { teacher competency. }\end{array}$ \\
\hline 2 & $\begin{array}{l}\text { Titus \& Annaraja } \\
\text { (2011). }\end{array}$ & $\begin{array}{l}\text { Teaching competency } \\
\text { of secondary teacher } \\
\text { education students in } \\
\text { relation to their meta- } \\
\text { cognition. }\end{array}$ & 600 Student Teachers & $\begin{array}{l}\text { There is a significant } \\
\text { relationship between meta- } \\
\text { cognition and teaching } \\
\text { competency of secondary } \\
\text { teacher education students. }\end{array}$ \\
\hline 3 & Jena (2012). & $\begin{array}{l}\text { Teaching aptitude of } \\
\text { Harijan Madhymik } \\
\text { Vidayalya teachers } \\
\text { in relation to their } \\
\text { teaching competency and } \\
\text { organizational climate. }\end{array}$ & $\begin{array}{l}100 \text { teachers as the } \\
\text { sample of the study. }\end{array}$ & $\begin{array}{l}\text { There is significant positive } \\
\text { relationship between } \\
\text { teaching aptitude and } \\
\text { teaching competency } \\
\text { of Harijan Madhymik } \\
\text { Vidayalya science and arts } \\
\text { teachers. }\end{array}$ \\
\hline 4 & $\begin{array}{l}\text { Kaur \& Talwar } \\
\text { (2014) }\end{array}$ & $\begin{array}{l}\text { Teaching Competency } \\
\text { of Secondary School } \\
\text { Teachers In Relation To } \\
\text { Emotional Intelligence. }\end{array}$ & $\begin{array}{l}100 \text { secondary school } \\
\text { teachers. }\end{array}$ & $\begin{array}{l}\text { There is a positive } \\
\text { correlation between teaching } \\
\text { competency and emotional } \\
\text { intelligence of secondary } \\
\text { school teachers, }\end{array}$ \\
\hline 5 & Kaur (2017) & $\begin{array}{l}\text { Study of teacher efficacy } \\
\text { of secondary school } \\
\text { teachers in relation to } \\
\text { their teaching competency }\end{array}$ & $\begin{array}{l}200 \text { urban and rural } \\
\text { secondary school } \\
\text { teachers }\end{array}$ & $\begin{array}{l}\text { There is significant } \\
\text { difference between teacher } \\
\text { competency of urban and } \\
\text { rural secondary school } \\
\text { teachers. }\end{array}$ \\
\hline 6 & $\begin{array}{l}\text { Choudhury \& } \\
\text { Chowdhury (2015). }\end{array}$ & $\begin{array}{l}\text { Teaching Competency } \\
\text { of Secondary Teacher } \\
\text { Educators In Relation } \\
\text { To Their Meta-cognition } \\
\text { Awareness. }\end{array}$ & 170 student teachers & $\begin{array}{l}\text { There is a significant } \\
\text { relationship between } \\
\text { teaching competency and } \\
\text { Meta-cognition awareness of } \\
\text { secondary teacher educators. }\end{array}$ \\
\hline
\end{tabular}




\begin{tabular}{|c|l|l|l|l|}
\hline 7 & Prasad (2014). & $\begin{array}{l}\text { Effect of Teacher } \\
\text { Training Programme } \\
\text { on Self-Concept, Self- } \\
\text { Confidence, Teaching } \\
\text { Competency, and Role } \\
\text { Commitment of Special } \\
\text { Teacher Trainees }\end{array}$ & $\begin{array}{l}150 \text { Special Teacher } \\
\text { trainees }\end{array}$ & $\begin{array}{l}\text { There is significant effect of } \\
\text { teacher training programme } \\
\text { on teaching competency of } \\
\text { orthopedic special teacher } \\
\text { trainees. }\end{array}$ \\
\hline 8 & Shukla (2014). & $\begin{array}{l}\text { Teaching competency, } \\
\text { professional commitment } \\
\text { and job satisfaction-a } \\
\text { study of primary school } \\
\text { teachers. }\end{array}$ & $\begin{array}{l}100 \text { primary school } \\
\text { teachers }\end{array}$ & $\begin{array}{l}\text { The result shows very low } \\
\text { positive correlation between } \\
\text { teaching competency and job } \\
\text { satisfaction. }\end{array}$ \\
\hline 9 & $\begin{array}{l}\text { Kartik \& Ahuja } \\
\text { (2016) }\end{array}$ & $\begin{array}{l}\text { Comparative Study of } \\
\text { Teaching Competency } \\
\text { of Male and Female } \\
\text { Trainees of Govt and Self } \\
\text { Financed Colleges. }\end{array}$ & $\begin{array}{l}\text { 100 B.T.C teacher } \\
\text { Trainees }\end{array}$ & $\begin{array}{l}\text { Male B.T.C. trainees were } \\
\text { superior to female B.T.C } \\
\text { trainees with regard to their } \\
\text { teaching competency on } \\
\text { post- instructional skills. }\end{array}$ \\
\hline 10 & Jahan & $\begin{array}{l}\text { A comparative study of } \\
\text { teaching competency of } \\
\text { elementary teacher in } \\
\text { gaya district of bihar }\end{array}$ & $\begin{array}{l}\text { 100trained } \\
\text { elementary school } \\
\text { teachers }\end{array}$ & $\begin{array}{l}\text { Teachers trained through } \\
\text { ODL mode by SCERT } \\
\text { showed better teaching skills } \\
\text { through Regular mode. }\end{array}$ \\
\hline
\end{tabular}

\section{Content analysis of Teaching Competency in} CBSE Books

It includes Lesson/chapter/unit, Title/theme, and Total no. of pages, remarks, suggestions and work out/projects/activities. The researcher has analyzed all the parameters while analyzing the content and visuals that have been given in the dimensions. According to (Alnoor, Yuanxiang, \& Abudhuim (2007)) Assessment Mathematics Teacher's Competencies such as,

- Preparation competencies and planning the lesson

- Competencies in carrying out the lesson

- Assessment competencies

- Educational means and equipment

- Personal competencies

\section{Text Book Content Analysis from Teaching} Competency Perspective

1. Lesson: 1

2. Title: Knowing our Numbers

3. Total no. of. Pages: 1-27

4. Preparation competencies and planning the lesson: Simply explain the number, preparation and planning are included, the teacher wants to prepare the greatest number; make numbers, estimating the numbers. the teacher wants to plan how to teach numbers, examples of large and small numbers

5. Competencies in carrying out the lesson: easy to take; Teacher wants to competency to teach the differentiation of numbers, sum and difference needs to explain different examples.

6. Assessment competency: Assessment competency is mentioned in the content, (Try these) tables are used to teacher assess the students understanding and knowledge of the specific content.

7. Educational means and equipment: Teachers can use educational equipment. (Sohan and Rita went to buy an almirah. There were many almirahs available with their price tags) The teacher can use teaching aids and equipment or some visual equipment was used to understand the numbers.

8. Personal Competencies: Personal Competency is required to take classes easily understand for the students. Personal competency is used to understand the number value in real-life examples. 
Suggestions: illustration should be clear.

Work out/ project/ Activities: Work out also helps children connect with their real-life by acquainting children with visuals and content. It helps children to promote their critical thinking, imagination and creativity. Visual activities can make the subject easy.

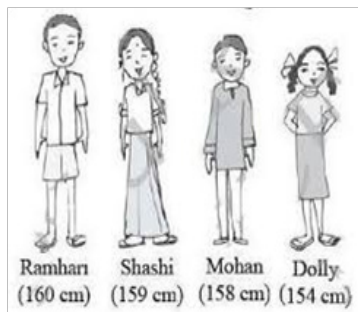

Figure 1: Representation of arranging the class students in descending order based on height. (NCERT, 2019)

1. Lesson: 2

2. Title: whole numbers

3. Total no. of Pages: $28-45$

4. Preparation competencies and planning the lesson: preparation and planning are required for whole number content because they needs to prepare more teaching aids base on the addition and multiplication of whole numbers.

5. Competencies in carrying out the lesson: competencies are required.

6. Assessment competency: Assessment competency is mentioned

7. Educational means and equipment: Educational equipment are mentioned

8. Personal Competencies: teacher's competency will apply the (try these) part and real-life examples.

Suggestions: illustrates are given very clearly.

Work out/ project/ Activities: activity based on division, multiplication and real-life examples

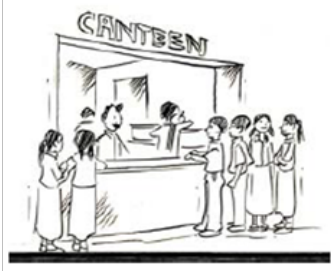

Figure 2: Representation of spending money for purchasing things in school canteen (NCERT, 2019)
1. Lesson : 3

2. Title: Playing with Numbers

3. Total no. of pages:46-68

4. Preparation competencies and planning the lesson: planning and preparation are required for this session. Because teacher needs to arrange the playing games like 50 cards about spotting factors and factor tree teaching aids.

5. Competencies in carrying out the lesson: competencies is not required, in this section teacher required to numerous good behavior and handle the class based on students performance.

6. Assessment competency: Assessment is mentioned

7. Educational means and equipment: Educational teaching aids are necessary for teach playing games.

8. Personal Competencies: Personal competency is not essential.

Suggestions: demonstrate is given properly; reallife examples can make easy of the subject. (In a morning walk, three persons step off together. Their steps measure $80 \mathrm{~cm}, 85 \mathrm{~cm}$ and $90 \mathrm{~cm}$, respectively. What is the minimum distance each should walk so that all can cover the same distance in complete steps?)

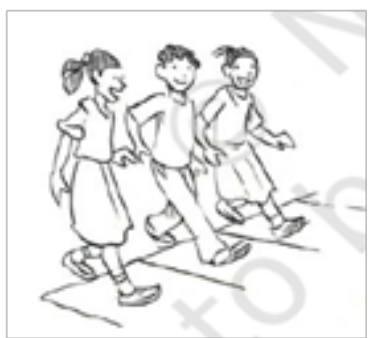

Figure 3: Representation of Playing with

Numbers based on the physical exercise (NCERT, 2019)

Work out/ project/ Activities: Less activity only noted. Tests for divisibility numbers and LCM and HCF activity are not mentioned. Exercise problem noted for all chapters.

1. Lesson: 4

2. Title: Basic Geometrical Ideas

3. Total no. of Pages:69-85

4. Preparation competencies and planning the lesson: Teachers' preparation important for 
geometry sessions, teachers' planning and preparation part is necessary for this section. Teachers plan how to teach shapes different shapes in real-life activity and teachers prepare the teaching aids based on shapes and angles.

5. Competencies in carrying out the lesson: competencies are not carried in this lesson.

6. Assessment Competency: Assessment is not mentioned, just shapes only mentioned.

7. Educational means and equipment: Educational equipment is only necessary $\mathrm{n}$ this geometry paper based on the 6th book.

8. Personal Competencies: Personal competency based on application skill only required for teachers

Suggestions: Illustration is given properly but student's activity is less, teachers' movement is more in this section.

Work out/ project/ Activities: More than real life examples are given in this section for shapes such as,
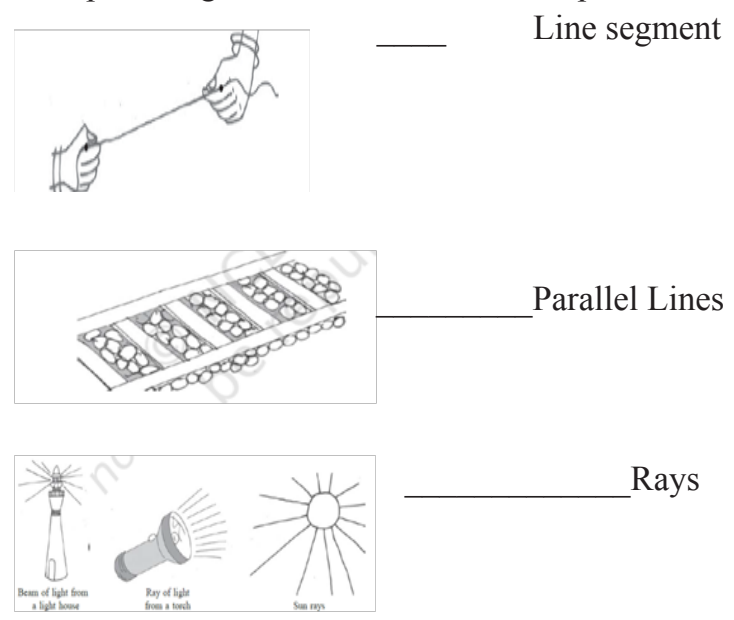

\section{Figure 4: Representation of Basic Geometry based on the line segments using threats, Railway track explains parallel lines and lights explains rays (NCERT, 2019)}

1. Lesson: 5

2. Title: Understanding Elementary Shapes

3. Total no. of Pages: 86-112

4. Preparation competencies and planning the lesson: Preparation and planning is not required

5. Competencies in carrying out the lesson: Managerial competency is carried out the lesson
6. Assessment competency: Assessment is required

7. Educational means and equipment: geometrical equipment only need for measurement.

8. Personal Competencies: Personal competency is not based on chapter

Suggestions: explanation is smaller than the exercise part

Work out/ project/ Activities: Exercise is given, for one section gave max 8 exercise problems

1. Lesson: 6

2. Title: Integers

3. Total no. of Pages: 113-132

4. Preparation competencies and planning the lesson: Planning and preparation is not required

5. Competencies in carrying out the lesson: competencies is carrying in the examples of integers

6. Assessment competency: The assessment part is mentioned for Do this part

7. Educational means and equipment: Educational equipment is not mentioned more; few examples are only given.

8. Personal Competencies: Personal competency is not required

Suggestions: Illustration is given but is not more about integers

Work out/ project/ Activities: Exercise part more, real-life examples and project activity is less

1. Lesson: 7

2. Title: Fractions

3. Total no. of Pages:132-163

4. Preparation competencies and planning the lesson: Preparation and planning are needed for this session, teachers prepare teaching aids based on fractions and a working model is necessary for this session.

5. Competencies in carrying out the lesson: Teachers application and knowledge is required,

6. Assessment competency: Assessment is mentioned

7. Educational means and equipment: educational equipment is noted in this chapter like shapes such as, 
Recall the pooris eaten by Farida. She got $2 \frac{1}{2}$ poories (Fig 7.9), i.e.

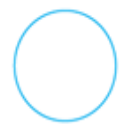

This is 1

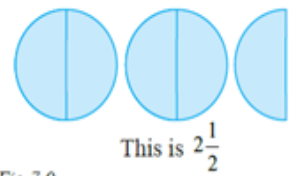

Figure 5: Representation of circles explains the Fractions of values such as full, half and semi half. (NCERT, 2019)

8. Personal Competencies: Teachers use personal competency-based on life activity examples.

Suggestions: illustration is proper

Work out/ project/ Activities: workout and project activity based on real-life examples

1. Lesson: 8

2. Title: Decimals

3. Total no. of Pages: 164-184

4. Preparation competencies and planning the lesson: planning and preparation is not necessary for this chapter

5. Competencies in carrying out the lesson: competency is not required for the specific content of decimals in this book

6. Assessment competency: Assessment is available

7. Educational means and equipment: educational equipment is not mentioned more; only blackboard activity only need for the teacher

8. Personal Competencies: Teaching Skill (blackboard) is necessary.

Suggestions: The example part is very less compare to the do this and exercise part.

Work out/ project/ Activities: do this and the exercise part is given to students.

1. Lesson: 9

2. Title: $184-205$

3. Total no. of Pages: Data Handling

4. Preparation competencies and planning the lesson: presentation and planning are required for teachers; teachers need to prepare the proper teaching aids depend on data.

5. Competencies in carrying out the lesson: Teachers needs to be competency to teach the data handling based on the CBSE book.

6. Assessment competency: evaluation quality is required for assesses the graph.

7. Educational means and equipment: educational equipment is not necessary because in this chapter is based on student's activities.

8. Personal Competencies: personal competency is not mentioned

Suggestions: Illustration is proper, exercise part is very less.

Work out/ project/ Activities: work out and given, only project activities are not exercise

1. Lesson: 10

2. Title: Menstruation

3. Total no. of Pages: 205-221

4. Preparation competencies and planning the lesson: Preparation and planning are required for this session; teacher's needs to give examples of perimeter and area of square shapes and rectangle shape.

5. Competencies in carrying out the lesson: competencies is carried out in this lesson base on a different kind of shapes perimeter

6. Assessment competency: evaluation part is required; basic addition and multiplication is necessary for this section

7. Educational means and equipment: educational equipment is based on shapes

8. Personal Competencies: Teachers can use a personal skill in this section.

Suggestions: illustration is clear.

Work out/ project/ Activities: project activities and work out based on real-life things, such as occupies more region based on area.

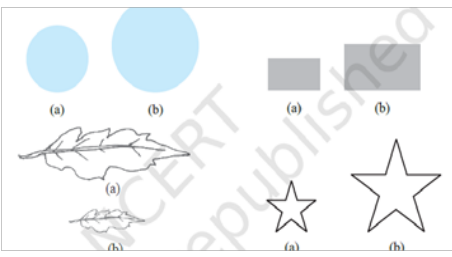

Figure 6: Representation of circle, rectangle, leaf and star sizes explain the occupying the space of the objects and Menstruation (NCERT, 2019)

1. Lesson: 11

2. Title: Algebra

3. Total no. of Pages: 221-244tion 
4. Preparation competencies and planning the lesson: Planning and preparation are compulsory for algebra; in this book, algebra more movement based on the teacher.

5. Competencies in carrying out the lesson: competencies is carried out in this lesson

6. Assessment competency: Assessment is not mentioned

7. Educational means and equipment: Educational aids are not required; teacher talk and student listening only important in this chapter

8. Personal Competencies: The teacher can use personal competency in this chapter.

Suggestions: Illustration is not given more

Work out/ project/ Activities: project activity is not given; exercise problem only used to evaluate the students

1. Lesson: 12

2. Title: Ratio and Proportion

3. Total no. of Pages: $244-260$

4. Preparation competencies and planning the lesson: Preparation and planning are not necessary for in this chapter CBSE book, basic small division and a small number of ratio only mentioned.

5. Competencies in carrying out the lesson: Competencies are carried out in the lesson for real-life examples.

6. Assessment competency: Assessment competency is not mentioned

7. Educational means and equipment: Educational equipment is not given much more importance.

8. Personal Competencies: Teachers must want to teach a personal skill

Suggestions: illustration is given more

Work out/ project/ Activities: visual examples can make easy to understand and exercise part also given visual examples such as, (which one is above the value of ratio?)

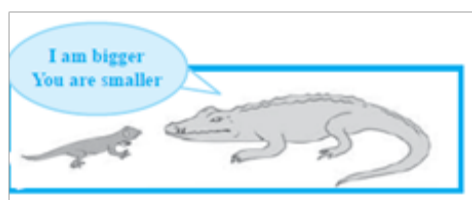

Figure 7: Representation of animals explains the size of ratio and proportion (NCERT, 2019)
1. Lesson: 13

2. Title: Symmetry

3. Total no. of Pages:261-274

4. Preparation competencies and planning the lesson: Preparation and planning is a must for in this chapter; in this chapter teacher need to prepare the more symmetric and nonsymmetric shapes for teaching.

5. Competencies in carrying out the lesson: Competencies is not carried out in this lesson

6. Assessment competency: Assessment competency is required for in this section, the teacher can evaluate the students in a classroom activity.

7. Educational means and equipment: educational equipment is necessary for this chapter.

8. Personal Competencies: Teachers should apply personal skills based on real-life examples of symmetry.

Suggestions: Illustration and examples are very clear.

Work out/ project/ Activities: project activities are given in this book based on real-life situations.

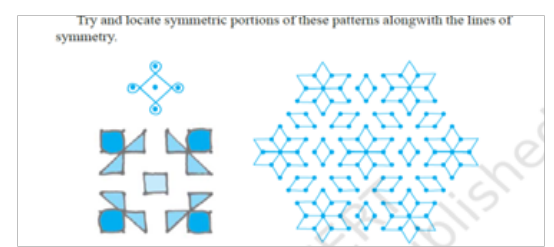

Figure 8: Representations of some common shapes based on the symmetric portions of the patterns (NCERT, 2019)

1. Lesson: 14

2. Title: Practical Geometry

3. Total no. of Pages: 274-292

4. Preparation competencies and planning the lesson: Preparation and planning are not required; student's parts are more important in this session.

5. Competencies in carrying out the lesson: Competencies can apply to the teacher in this session to take correct measurements and clean diagrams.

6. Assessment competency: Assessment competency important in this session for evaluates student efficiency of the diagram. 
7. Educational means and equipment: Educational equipment is necessary to measure the values.

8. Personal Competencies: Personal competency can use draw the geometry clear and correct measurement
Suggestions: illustration is very clear

Work out/ project/ Activities: visual examples are given for easy understand and more exercise parts given

\section{Teaching Competency Process}

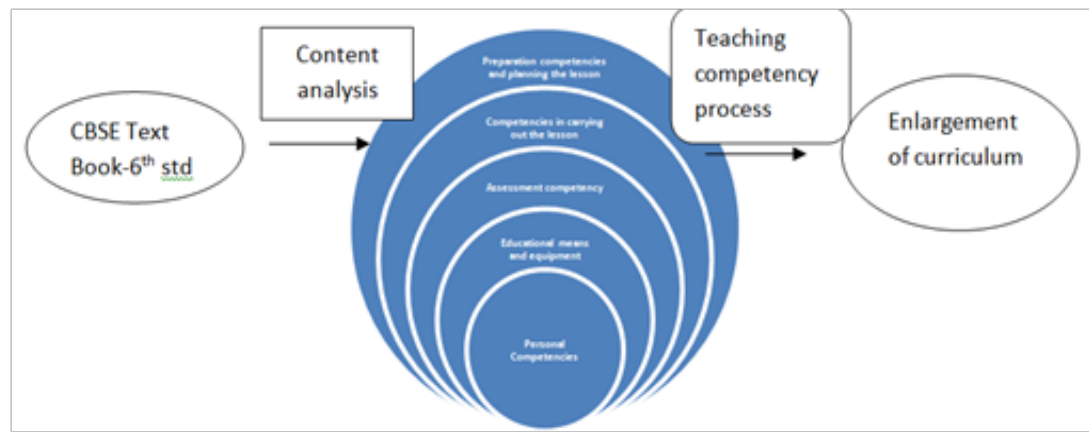

Figure 9: Representation of Conceptual Diagram school textbook analysed by the teaching competency dimensions and helps to enlarge the curriculum

\section{Conceptual Diagram Explanation}

CBSE -6th standard Mathematics book was used to analyze the content. This study using the mathematics teaching competency dimensions to analyze the textbook. Each content analyzes different dimensions and categories like title, no.of. pages, suggestion and workout/project activity. I am teaching competency dimensions used to process the content and produce valuable results about textbooks.

The processing of teaching competency in textbooks is used to enlarge the curriculum in mathematics CBSE 6th book.

From the content analysis of the textbook, the researcher find some valuable suggestions such as,

- Illustration is clear

- Necessary of workout/Project activity part

- Necessary of more and easy exercise problem

- Teaching aids necessary part in subjects such as geometry, measurement, etc.,

From the above statements, the researcher found the details and given some suggestions about the CBSE school textbook.

\section{Conclusion}

The study is based on content analysis of the CBSE 6th standard Maths textbook using teaching competency dimensions. Given the above discussion, it can be concluded that most of the teaching competency dimensions more impact the 6th standard mathematics school text.

\section{Reference}

“NCERT Books for Class 6 Maths." BYJU'S, https:// byjus.com/ncert-books-class-6-maths/

Ahmad, Jarrar, and Mohd. Ahmad Khan. "A Study of Teaching Competency of Secondary School Teachers in Relation to their Educational Qualification, Stream and Type of School." International Journal of Applied Research, vol. 2, no. 2, 2016, pp. 68-72.

Alnoor, A.G., et al. Assessment Mathematics Teacher's Competencies. 2007.

Choudhury, Sukla Roy, and Susanta Roy Chowdhury. "Teaching Competency of Secondary Teacher Educators in Relation to Their Metacognition Awareness." International Journal of Humanities and Social Science Invention, vol. 4, no. 1, 2015, pp. 17-23.

Jena, Prakash Chandra. "Teaching Aptitude of Harijan Madhymik Vidayalya Teachers in Relation to their Teaching Competency and Organizational Climate." International Journal of Education and Psychological Research, vol. 1, no. 1, 2012, pp. 19-29.

Kalaiselvi, T. "Teaching Competencies." The Hindu, 2017. 
Kartik, Priyanka, and Malvinder Ahuja. "Comparative Study of Teaching Competency of Male and Female Trainees of Govt and Self Financed Colleges." IRA International Journal of Education and Multidisciplinary Studies, vol. 4, no. 2, 2016, pp. 278-288.

Kaur, Mandeep, and Arti Talwar. "Teaching Competency of Secondary School Teachers in Relation to Emotional Intelligence." International Journal of Learning, Teaching and Educational Research, vol. 3, no. 1, 2014, pp. 83-90.

Kaur, Parmjot. "Study of Teacher Efficacy of Secondary School Teachers in Relation to their Teaching Competency." International Education and Research Journal, vol. 3, no. 4, 2017.

Prasad, Rajendra. "Effect of Teacher Training
Programme on Self-Concept, SelfConfidence, Teaching Competency, and Role Commitment of Special Teacher Trainees." American Journal of Educational Research, vol. 2, 2014, pp. 22-30.

Shukla, Shashi. "Teaching Competency, Professional Commitment and Job Satisfaction - A Study of Primary School Teachers." Journal of Research \& Method in Education, vol. 4, no. 3, 2014, pp. 44-64.

Titus, Sheeja V., and P. Annaraja. "Teaching Competency of Secondary Teacher Education Students in Relation to their Meta-cognition." International Journal on New Trends in Education and their Implications, vol. 2, no. 3, 2011, pp. 14-22.

\section{Author Details}

G. Manimozhi, Department of Education, Research Scholar, Central University of Tamil Nadu, Thiruvarur, India, Email ID: manimozhiedu16@students.cutn.ac.in.

P. Srinivasan, Departments of Education, Associate Professor, Central University of Tamil Nadu, Thiruvarur, India. 